\title{
Research on ROI of Stadium in Health Industry
}

\author{
Zhihong Li \\ College of physical education, Hubei Normal University, Huangshi Hubei, 435002, China
}

Keywords: Health industry, Stadium construction, ROI.

\begin{abstract}
Currently, Chinese sports cause is facing increasing new development chances. It requires various investments to develop health and sports industry. Stadium construction is an important aspect. Local government $\mathrm{s}$ and some public interest organizations are enhancing stadium construction, but how to make use of its effect after the completion is a question to be thought of. The article starts from the general situation of stadium construction in health industry, and then makes analysis on ROI of stadium so as to make full use of its best advantages.
\end{abstract}

\section{Introduction}

With the 2008 Beijing Olympic successfully held in China, a trend of bodybuilding has prevailed around the whole country. The health industry has developed into the newly sunrise industry. This has shown that people are paying more and more attention to fitness and health. The booming of health industry has also attracted investments from various enterprises and social capitals. Enterprises participate in the health industry in various ways. Constructing stadiums is one of the most common one and it turns out to be a successful form during the development process. When enterprises are constructing stadiums, the main problem for them is how to get investment return through stadium construction or how to obtain favorable profit scale for stadiums. This issue has been the biggest question since enterprises starts investing stadium construction. On one hand, the construction is an important part to promote Chinese health industry development, and on the other hand, stadium construction requires large amount of fund to support. It is not workable just by means of governmental investments. Bringing in the investments from social capitals is required, i.e. enterprise investment. Another outstanding problem when enterprises are investing to construct stadium is that they cannot receive corresponding profit return afterwards and even they cannot get back the invested fund. This phenomenon is a very common phenomenon in the process of enterprises' investing to construct stadium $^{\mathbf{1} 1 \mathbf{1}}$.

\section{Analysis on current situation of stadium ROI}

\section{Small revenue size}

A ubiquitous problem when Chinese enterprises are investing to construct stadium is that the revenue size of stadium operation is small. This has not only greatly eliminated enterprises motivation to invest stadiums, but also hindered the stadium smooth running and development. It will also give enterprises an incorrect conception that investing stadiums cannot get good returns. Thus they will go into a vicious circle which will heavily hinder the development of Chinese health industry. The problem of small revenue size is reflected on many aspects. For example, there are no large-scale customers received in the stadium to consume, stadium is poor equipped with facilities, no more consumptions can be produced, related catering, bath and rest service is not in place so as not to have the capacity for customers 'consumption. All of these will lead to the small revenue size of stadium operation. In addition, except for providing ordinary bodybuilding for customers, another primary 
function is to hold various contests and concerts and other activities. But some stadiums have no clear clues on how to produce considerable profits. This makes stadium lose a large part of revenue sources in the management. It can be said that the problem of small revenue size is the biggest factor to prevent enterprises participate in stadium construction in large scale, and it has heavily impacted the stadium operation and development, extremely unfavorable for Chinese health industry development.

\section{Rigid profit model}

At present stadium construction with Chinese enterprises participated in are most built under the guidance of local government. But enterprises have not yet developed a set of successful and thorough profit model for stadium operation. For stadium operated by enterprises, most of the profit models are rigid or traditional charge model. Under current health industry development situation, it is rigid not capable to adapt to the development requirement so as not to bring large-scale profits to stadium management or favorable return to invested enterprises. The rigid profit model lies in that enterprises do not make effective innovation during stadium construction. Running stadium is not just providing bodybuilding place or activity place, but more often it provide the fitness service and related supporting service. The overall developing trend of health industry is inevitably the same. Enterprise should take the initiative to think about how to bring better fitness experiences and providing better bodybuilding or other service. It can be said that the reason why many enterprises cannot get favorable profits and returns during stadium operation to a large extent is because of the current rigid profit model. This has also greatly limited the improvement of the profit scale. Rigid profit model firstly is reflected on that enterprises' leadership is short of stadium operation perception. When investing to construct stadium, enterprise leadership has no clear understanding on how to conduct stadium operation and how to obtain profits. This has directly lead to the rigidity of profit model in stadium operation ${ }^{\mathbf{2} \mathbf{}}$.

\section{Deficiency in operation and management}

During the process of enterprise running stadium, there are deficiencies in the operation and management. Stadium operation is different with enterprise management. Enterprise operation activities may not be suitable for stadium operation. There are not many successful experiences and models to be reference for enterprises to run stadiums. This results in deficiencies when Chinese enterprises are operating and running stadium. Operating management is critical for stadium daily running and development, and is directly influencing the profit return. The reason why many stadiums cannot make ends meet and cannot fulfill large-scale earning is because of the poor operation and management. It can be said that if enterprises want to obtain objective profits through stadium investments, they must pay attention to stadium operating management and adjust operating management method according to the particularity of stadium so as to get the best effect. The operating management problems for Chinese enterprise to run stadiums are mainly the management model and method. For example, for customers take daily exercise in the stadium, the stadium is short of a humanized management method. People oriented and customer orientation has been ignored. There is an absence of innovation on operating management model so that more customers cannot be attracted effectively and favorable profits cannot be achieved.

\section{Countermeasure to problems of ROI on enterprises' constructing stadium}

\section{Expand the profit scale}

There is no doubt that expanding the profit scale is the most powerful way to get good returns if investing stadiums. How can it be fulfilled? It requires enterprises to voluntarily think and improve according to the special situation of stadium earning. Improving according the practical operation and customer condition in the stadium, and providing customer more comprehensive service is the most effective way to expand the stadium profit scale. Enterprises should bring more commercial elements into stadium in the operating management with bodybuilding as the core to provide better service and exercising experience. Although the main function of stadium is to provide place to exercise and hold activities, for operators of stadiums, there are far more services can be provided such as the related 
construction supporting service, bath, catering, rest, entertainment, etc so as to make it a comprehensive fitness and recreation place for customer to take exercise and relax. Stadium as an important component in health industry, can conduct related commercial business centered on health. Stadiums can promote related health service to consumers with health as the selling point to increase profitable items and expand the profit scale. In addition, stadium is not only the place for consumers to exercise, but also the place to hold sports contests and large-scale activities. Enterprise can make full use of this function during the stadium operation. They can get profits not only dependent on charging rents but also some other commercial service. This is also an effective way for stadiums to expand profit scale.

\section{Innovative profit model}

It is necessary for enterprise to innovate the profit model when running stadiums. Traditional stadium profit model is still left behind on the aspect of humanization. They have not made full use of the unique advantages of stadium itself. Therefore stadiums cannot effectively improve the profit level to get favorable return for invested enterprises. Regarding this issue, enterprise as the operator should voluntarily innovate the stadium operation method and profit model so as to be more humanized. For example, membership system can be used on the public exercising function of stadium which can effectively maintain old customers but also can bring better fitness and exercising experience for

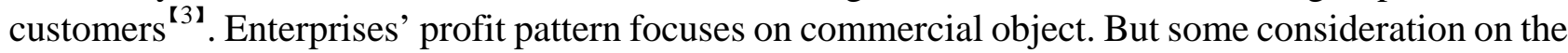
public welfare of stadium will also bring social appraises for stadiums so as to enhance the stadium reputation and bring in more profits. Thus, enterprises should have a long-term vision and focus on future and stadium long-term development.

\section{Consummate operating management}

Operating management is a very important part for stadium commercialization, especially for stadium invested and operated by enterprises. Enterprises must pay large amount of costs to invest and construct stadiums, so they should strengthen the stadium daily operating management for cost recovering and large-scale earning. Stadium operating management is different with company and ordinary service place. Stadium mainly provides services of construction, sports equipment and the site especially for holding activities. His requires enterprises to make changes according to the specialty of stadium operation during the management process instead of applying enterprise management pattern simply and mechanically. The important function of operating management is not just to maintain stadium daily running, but also to effectively lower the operating costs of stadiums. In stadium operating management there should be a well-developed plan and strict management measures on stadium operating costs. Only by effectively lowering the stadium operating costs can it get favorable profit returns. Enterprises should have a correct understanding on this. Moreover, it requires the enterprise leadership to pay more attention to their awareness to perfect stadium operating management. In stadium operating management system, management department should be established by specially-assigned personnel in charge of stadium daily operating management and detection of various problems for timely correction. These measures are effective ways to improve stadium profit level and ensure the long-term development.

\section{Conclusion}

The development of health industry has brought great opportunities. Stadium as an important link in health industry has become one of the important approaches for enterprises to invest health industry. During the process of enterprise investing stadium construction and operation, a main problem is that the return stadiums has brought to enterprises is barely satisfactory and even some stadiums operated by enterprises cannot make the ends meet. There are many factors such as profit model, operating management, etc. These problems must be settled down so that enterprise can fulfill the goal of obtaining maximum profit scale by investing stadiums. With the development of Chinese health industry, people are paying more attention to fitness and exercise, and enterprise surely will obtain better returns through stadium investments. 


\section{References}

[1] [1]Yang Fenghua, Effective supply from public stadium service. Beijing Sport University, 2007

[2] [2]Yu Huiqing, Zhang Hong, Brief analysis on operation and management of large-scale stadium. Journal of Guangzhou Sport University, 2002, 03:27-28+31.

[3] [3]Zhang Xiaogang. Management model and design of stadium. Tongji University,2007 